\title{
The Detection of Plant Viruses in Korean Ginseng (Panax ginseng) through RNA Sequencing
}

\author{
Hong-Kyu Lee ${ }^{1}$, So-Yeon Kim ${ }^{1}$, Hee-Ji Yang ${ }^{1}$, Da-Som Lee ${ }^{1}$, Boram Kwon ${ }^{1}$, Dong-Yun Lee ${ }^{2}$, Jonghee Oh ${ }^{1 *}$, \\ and Su-Heon Lee ${ }^{1,3 *}$ \\ ${ }^{1}$ School of Applied Biosciences, Kyungpook National University, Daegu 41566, Korea \\ ${ }^{2} R \& D$ Headquarters, Korea Ginseng Corporation, Daejeon 34128, Korea \\ ${ }^{3}$ Institute of Plant Medicine, Kyungpook National University, Daegu 41566, Korea \\ (Received on July 23, 2020; Revised on October 31, 2020; Accepted on November 12, 2020)
}

Korean ginseng (Panax ginseng) is a dicotyledonous, medicinal, perennial plant belonging to the genus Panax of the family Araliaceae. We investigated the occurrence and incidence of plant viruses in Panax ginseng in Korea. A total of 656 leaf samples were combined into one and total RNA was extracted from the polled sample, using RNA sequencing (RNA-Seq), a metatranscriptome analysis of the plant virome was conducted. The virus present in Panax ginseng was confirmed by reverse transcription polymerase chain reaction (RT-PCR) assay using virus-specific primers. In RNA-Seq data analysis, the multiplication protein of four viral contigs including Aristotelia chilensis virus 1 (AcV1), Turnip mosaic virus (TuMV), Watermelon mosaic virus (WMV), and Tobamovirus multiplication protein were discovered. From our metatranscriptome analysis and RT-PCR assay, TuMV and WMV were detected, whereas the three viruses reported in China such as tomato yellow leaf curl China virus; panax notoginseng virus $A$; and panax virus $Y$ were not found in this study. The distribution of domestic ginseng viruses seems different from that recorded in China. Overall,

*Co-corresponding authors.

Jonghee $\mathrm{Oh}$

Phone) +82-53-950-5763, FAX) +82-53-950-6758

E-mail)jheeoh09@gmail.com

Su-Heon Lee

Phone) +82-53-950-5763, FAX) +82-53-950-6758

E-mail) suheon@knu.ac.kr

(c) This is an Open Access article distributed under the terms of the Creative Commons Attribution Non-Commercial License (http:// creativecommons.org/licenses/by-nc/4.0) which permits unrestricted noncommercial use, distribution, and reproduction in any medium, provided the original work is properly cited.

Articles can be freely viewed online at www.ppjonline.org. this is the first plant virome analysis of Panax ginseng in Korea.

Keywords : Panax ginseng, plant virome, RNA-Seq

Handling Editor : Ju-Yeon Yoon

Korean ginseng, traditionally referred to as "Insam" (Panax ginseng) is dicotyledonous, medicinal, perennial plant belonging to the genus Panax of the family Araliaceae; there are six species in the genus Panax ( $P$. ginseng, $P$. japonicum [Japanese ginseng], $P$. notoginseng [Chinese ginseng], $P$. pseudoginseng [Himalayan ginseng], $P$. quinquefolius [American ginseng], and P. trifolius [Dwarf ginseng]). In previous reports, six viruses were reported in the genus Panax: tomato yellow leaf curl china virus (TYLCCNV) (Li et al., 2014), panax notoginseng virus A (PnVA) (Guo et al., 2016), panax notoginseng virus $B$ (reported only in the NCBI GenBank, MF614102), panax notoginseng virus Y (reported only in the NCBI GenBank no., FJ816101), panax virus Y (PanVY) (Yan et al., 2010), and watermelon mosaic virus (WMV) (Jung et al., 2013). TYLCCNV belongs to a member of the genus Begomovirus and was reported in China. TYLCCNV-infected $P$. notoginseng shows foliar yellowing, shrinking, and blistering symptoms. Bemisia tabasi is known as a potential insect vector of TYLCCNV. PnVA belongs to a member of the genus putative Totivirus and has been reported in China. PnVAinfected $P$. notoginseng shows mild mosaic symptom. PanVY, as a member of the genus Potyvirus, has also been reported in China. PanVY-infected $P$. notoginseng shows typical distortion and mosaic symptoms. The pathogenicity of panax notoginseng virus $B$ and panax notoginseng virus $\mathrm{Y}$ is uncertain; only their nucleotide sequences have 
been reported in the GenBank database. In Korea, only the WMV has been reported in P. ginseng. The WMV is a member of the Potyvirus, which is the second largest genus of plant viruses based on the International Committee on Taxonomy of Viruses. The WMV strain Insam (WMVInsam) infecting $P$. ginseng was first reported in Korea using large-scale oligonucleotide chip and reverse transcrip- tion polymerase chain reaction (RT-PCR) assay (Jung et al., 2013). Unlike other WMV isolates that cause economic damage to the Cucurbitaceae, including cucumber, pumpkin, and watermelon, it has been known that the WMVInsam strain is not transmitted to the Cucurbitaceae plants by mechanical inoculation (Choi et al., 2014).

Due to the detection limit of conventional diagnostic
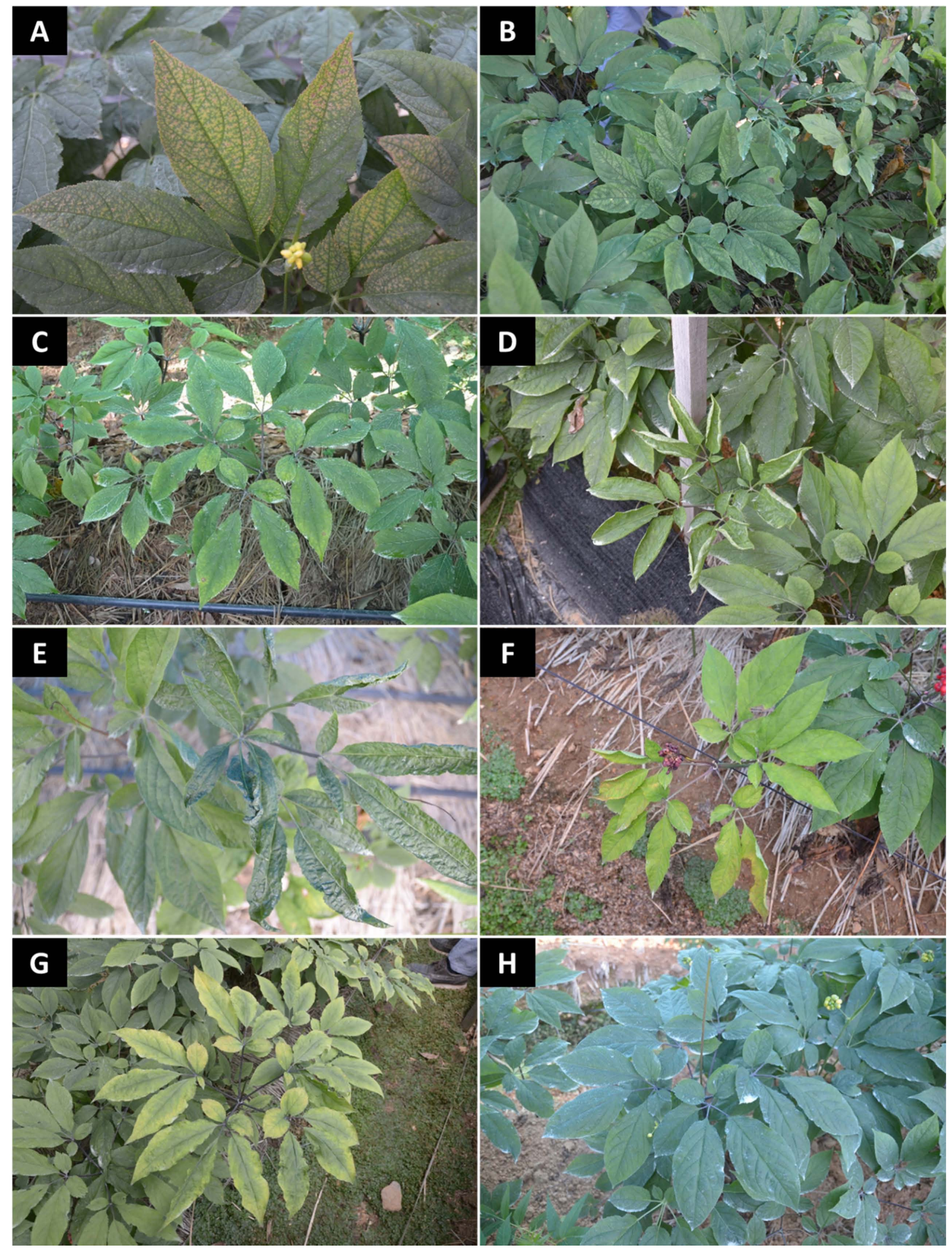

Fig. 1. Various symptom of Panax ginseng. (A) Chlorosis. (B) Vein banding. (C) Mosaic. (D) Leaf curl. (E) Malformation. (F) Yellowing. (G) Edge yellowing. (F) Symptomless. 
techniques (PCR and serological assay), it has not yet been clear what kind of virus infects $P$. ginseng and little is known about plant virus in $P$. ginseng in Korea. Recently, metatranscriptomic analysis with RNA sequencing (RNASeq) and RT-PCR have been used in diagnostic tools for detecting novel or unknown viruses and the confirmation of the presence of viruses (Min et al., 2017, Oh et al., 2018, Park et al., 2019, Yang et al., 2019). This study reports the first metatranscriptomic analysis of the $P$. ginseng virome using RNA-Seq and RT-PCR assay for identifying the occurrence and incidence of $P$. ginseng viruses in Korea.

Plant materials and growth conditions. To investigate the incidence and occurrence pattern of viruses in Korean ginseng plant, a nationwide virus survey of $P$. ginseng was conducted from July to August 2018. A total of 656 leaf samples of symptomatic plants (showing virus diseaselike symptoms such as chlorosis, vein banding, mosaic, leaf curl, malformation, yellowing, and edge yellowing) and asymptomatic plants were collected from 18 regions of the country (Yeoncheon, Yangpyeong, Yeoju, Anseong, Hwaseong, Icheon, Cheorwon, Hongcheon, Hoengseong, Seosan, Yesan, Sejong, Goesan, Chungju, Gochang, Namwon, Yeonggwang, and Gangjin) (Figs. 1 and 2); the samples then stored at $-80^{\circ} \mathrm{C}$ for analyses.
Total RNA extraction and RNA library construction. To construct the RNA library of $P$. ginseng viruses, all collected samples were combined into one sample and total RNA was extracted from the polled sample using a QuantIT RiboGreen (Invitrogen, Carlsbad, CA, USA). To assess the integrity of the total RNA, samples were subjected to the TapeStation RNA screentape (Agilent Technologies, Santa Clara, CA, USA). Only high-quality RNA preparations with RNA integrity number greater than 7.0 were used for RNA library construction. Total RNA quality and quantity were verified using a NanoDrop 1000 spectrometer (Thermo Scientific, Welmington, DE, USA) and Bioanalyzer 2100 (Agilent Technologies). A library was independently prepared with $1 \mu \mathrm{g}$ of total RNA using TruSeq Stranded Total RNA Sample Prep Kit (Illumina, San Diego, CA, USA). The rRNA in total RNA was depleted by TruSeq Stranded Total RNA with Ribo-Zero Plant kit (Illumina). Following the depletion of the rRNA, the remaining purified, fragmented, and primed RNA was used for cDNA synthesis. The cleaved RNA fragments were copied into the first-strand cDNA using reverse transcriptase and random hexamer (5'-NNNNNN-3').

De novo transcriptome assembly. One hundred bp pairedend $(2 \times 100 \mathrm{bp})$ RNA-Seq based on next-generation se-

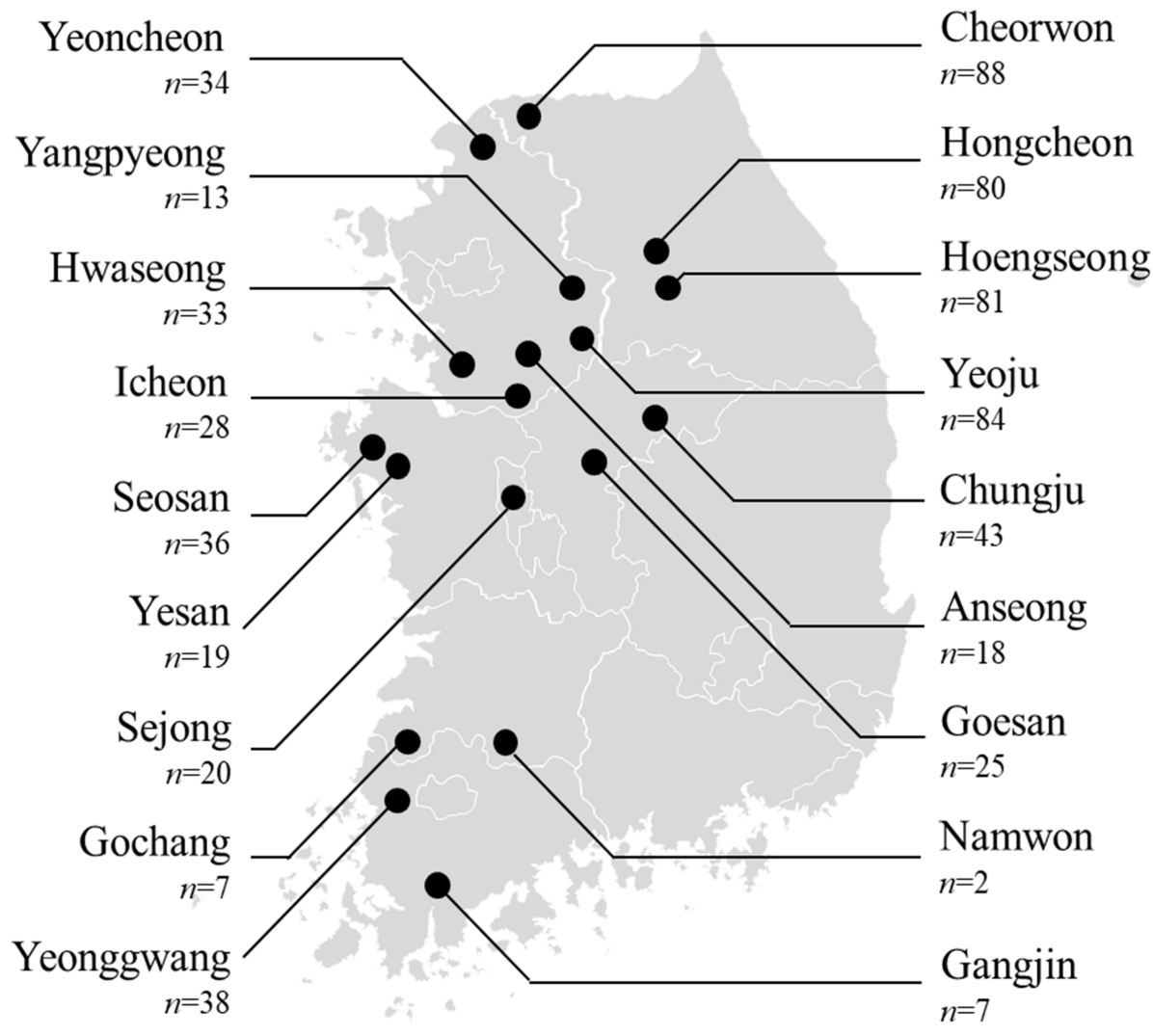

Fig. 2. The 18 locations of Panax ginseng cultivation areas and the number of samples collected from July to August 2018. $n$, number of collected samples. 
quencing (NGS) was performed using Illumina Hiseq 4000 sequencer by Macrogen Inc. (Seoul, Korea). The quality of the sequence was verified using FastQC v0.11.7. Before the commencement of the analysis, raw reads, adapter sequences, and low-quality read sequences were filtered using Trimmomatic 0.38 . Trimmed reads were assembled using a Trinity program with default parameters. The Trinity program was used for de novo transcriptome assembly, and was then assembled into transcript contigs. These contigs were further processed for read alignment and abundance estimation using Bowtie 1.1.2 and RSEM v1.2.29. The expression level of each contig was calculated using the fragments per kilobase of exon per million mapped fragments method, this was able to remove sequencing discrepancies in the calculation of gene expression and gene lengths. For annotation, the consensus sequences were searched against the GenBank non-redundant database (downloaded on May 3,2018 ) and gene ontology database (released on March 19, 2018) using BLASTx (v2.2.25).

Confirmation of RNA-Seq result using RT-PCR assay. To confirm the RNA-Seq result, the total RNA of the pooled leaf sample was extracted using the easy-spin Total RNA Extraction Kit (iNtRON, Seongnam, Korea) and following the manufacturer's instruction RT-PCR assay using
SR-8000 (GeNetBio, Daejeon, Korea) was conducted. The viral gene-specific primer, based on GenBank reference sequences and nucleotide sequences of the viral contigs from RNA-Seq, was designed for RT-PCR assay (Table 1). To verify the presence of reported viruses in $P$. notoginseng (TYLCCNV, PnVA, and PanVY) RT-PCR assay was performed using gene-specific primers (Table 1).

Metatranscriptomic analysis of plant virome from $\boldsymbol{P}$. ginseng. Thirty Gbp of raw data were generated from RNA-Seq. Following de novo transcriptome assembly, the sequences of 57,610 contigs were compared by BLASTn with nucleotide (nt) sequences in the NCBI database and 23 viral contigs were identified as follows: 2 contigs of Aristotelia chilensis virus 1 (AcV1, genus Petuvirus), 1 contig of Turnip mosaic virus (TuMV, genus Potyvirus), 17 contigs of WMV (genus Potyvirus), and 3 contigs of Tobamovirus multiplication protein (Table 2, Fig. 3, Supplementary Tables 1-3). Most WMV contigs identified were similar to other reported WMV-Insam strains with a nucleotide identity of $99-100 \%$. Among the identified viral contigs, small contigs that corresponds to the WMV with a length less than 1,000 nt were also found, but mostly covered complete genome of WMV-Insam strains (Fig. 3C). Thus, it appears to be the same WMV isolate previously

Table 1. List of primer set used for RT-PCR assay ${ }^{\mathrm{a}}$

\begin{tabular}{|c|c|c|c|c|}
\hline Name $^{b}$ & Primer set & Sequences ( $5^{\prime}$ to $\left.3^{\prime}\right)$ & Locations $^{c}$ & Expected size (bp) \\
\hline \multirow{2}{*}{ Tobamo } & Tob-Uni 2 & GTY GTT GAT GAG TTC RTG GA & $5,482-5,501$ & \multirow{2}{*}{805} \\
\hline & Tob-Uni 1 & ATT TAA GTG GAS GGA AAA VCA CT & $6,257-6,279$ & \\
\hline \multirow{2}{*}{ TuMV } & TuM-N60 & ACA TTG AAA AGC GTA ACC A & $9,329-9,347$ & \multirow{2}{*}{461} \\
\hline & TuM-C10 & TCA CCA CAT GCG CTA ACA CCA A & $9,768-9,789$ & \\
\hline \multirow{6}{*}{ WMV } & WMV-Pu-F24 & ATC AGA CAA CAT AAA CGC AAA CAA & $24-47$ & \multirow{2}{*}{572} \\
\hline & PGV-3R058 & GCA CAG CAG TTC CAC AGA CAT TAC & $557-580$ & \\
\hline & WMV-Pu-F33 & CAT AAA CGC AAA CAA ACT CTC AAG & $33-56$ & \multirow{2}{*}{585} \\
\hline & PGV-3R060 & ATA TTC TTC GCC ACT TTT GTC TGC & $579-602$ & \\
\hline & WMV2-N40 & GTT TAA CAC TCG AGC AA & $9,207-9,223$ & \multirow{2}{*}{613} \\
\hline & WMV2-C20 & CTT ATA ACG ACC CGA AAT GCT A & $9,798-9,819$ & \\
\hline \multirow{2}{*}{ TYLCCNV } & TYLCCNVFa & TGR TAG GWA CYT GAG TAG AGT GG & $1,557-1,579$ & \multirow{2}{*}{970} \\
\hline & TYLCCNVRa & TCR TCC ATC CAT ATC TTC CCA A & $638-659$ & \\
\hline \multirow{2}{*}{ PnVA } & PnVA-F & GTG GTA CAC TTT TGC TGG CG & $1,718-1,737$ & \multirow{2}{*}{469} \\
\hline & PnVA-R & GAC AGG TCC ACC CCA TTC AG & $2,167-2,186$ & \\
\hline \multirow{2}{*}{ PanVY } & CPJCF & GAC AAC AAC AAT GGA TGC & $8,549-8,566$ & \multirow{2}{*}{760} \\
\hline & CPJCR & ACT AAC ACT GCC ATC AAG & $9,288-9,305$ & \\
\hline
\end{tabular}

${ }^{\mathrm{a}}$ All reverse transcription polymerase chain reaction (RT-PCR) melting temperature was $55^{\circ} \mathrm{C}$.

${ }^{\mathrm{b}}$ Tobamo, Tobamovirus degenerated primer (Letschert et al., 2002); TuMV, Turnip mosaic virus (R.O.K. Patent No. 1006250190000) (Lee et al., 2006); WMV, Watermelon mosaic virus (Jung et al., 2013); TYLCCNV, Tomato yellow leaf curl China virus (Li et al., 2014); PnVA, Panax notoginseng virus A; PanVY, Panax virus Y (Yan et al., 2010).

${ }^{\mathrm{c}}$ Tobamo (accession no. MT107885), TuMV (MG200166), WMV (KP100058), TYLCCNV (KU934106), PnVA (KT388111) and PanVY (GQ916624). 
A Aristotelia chilensis virus 1 (AcV1) (KJ094314)
No. of virus contig $=2 / 23$

Length range $(\mathrm{nt})$ :

$\min =214 ; \max =299$

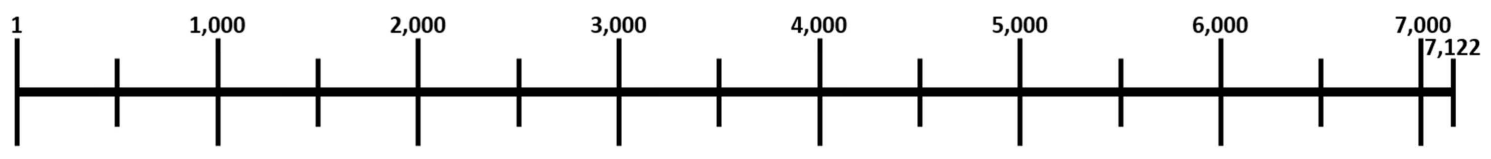

$\begin{array}{rcccc}6 & 214 & 28 & 284 \\ 645 & 853 & 3,485 & 3,741\end{array}$

B Turnip mosaic virus (TuMV)

(MH735111)
No. of virus contig $=1 / 23$

Length range (nt):

$\min =9,797 ; \max =9,797$
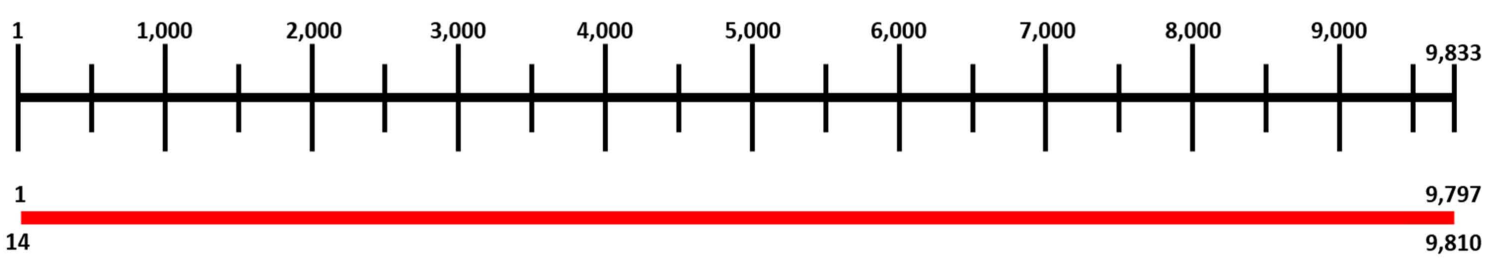

C

Watermelon mosaic virus (WMV) No. of virus contig $=17 / 23$

(KT992090)

Length range $(\mathrm{nt})$ :

$\min =202 ; \max =8,541$
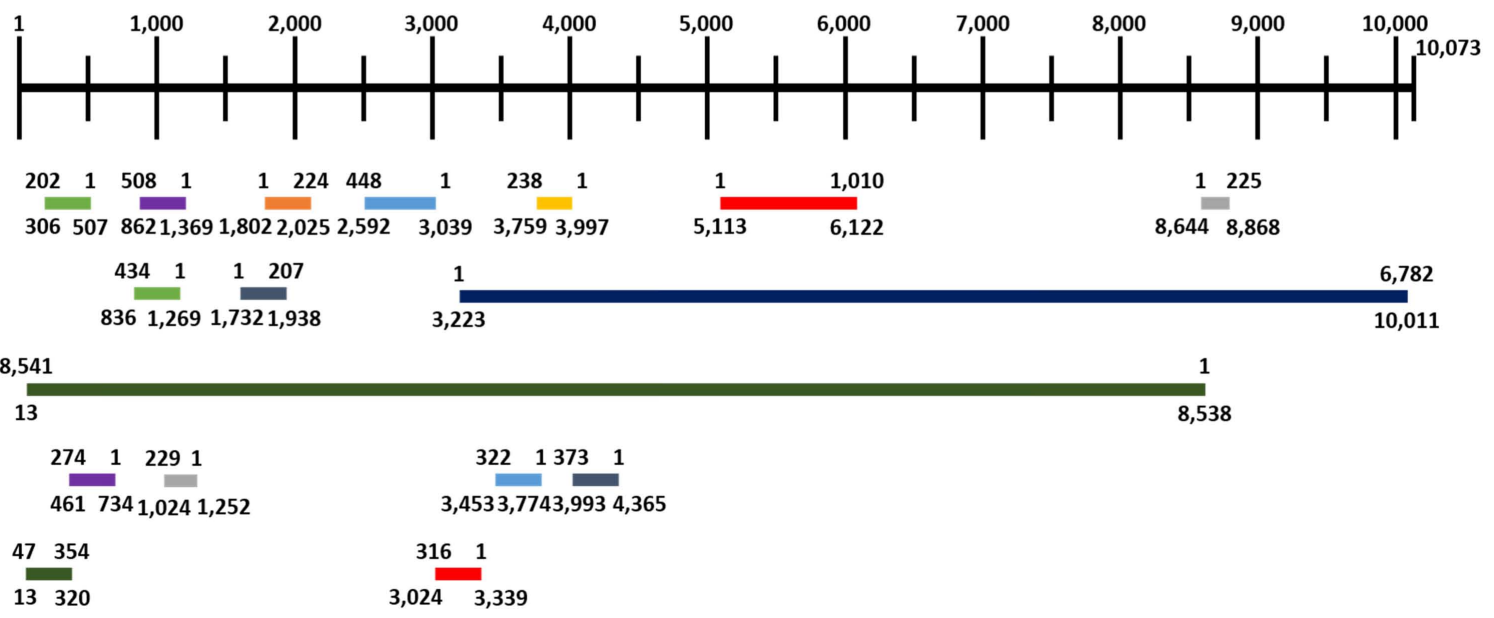

Fig. 3. Schematic overview of the alignment of contigs with NCBI reference sequences using BLASTn. (A) Aristotelia chilensis virus 1 (family Caulimoviridae, dsDNA). (B) Turnip mosaic virus (genus Potyvirus, ssRNA). (C) Watermelon mosaic virus (genus Potyvirus, ssRNA). Colored bar indicates contig from RNA-Seq; upper number indicates the sequence region or location of contig matching NCBI reference sequence; and lower number indicates the region or location within NCBI reference sequence matching contig sequence.

reported in the Korean ginseng plant.

RT-PCR assay for RNA-Seq data verification. In RNASeq analysis large contigs ( $>8,000 \mathrm{nt})$ corresponding to WMV and TuMV, were mainly identified (Fig. 3). To verify the RNA-Seq data in individual samples, RT-PCR assay was conducted using gene-specific primers to detect
TuMV (R.O.K. Patent No. 1006250190000) (Lee et al., 2006) and WMV (Jung et al., 2013). In RT-PCR assays for all collected samples (656 leaf samples), $3(0.46 \%)$ samples were TuMV-positive (two samples of Yeoju and one sample of Hoengseong) and 139 (21.2\%) samples were WMV-positive (Table 3). Interestingly, the infection rate of WMV showed noticeable regional differences, and 
Table 2. The annotated viral contigs from metatranscriptome analysis of Panax ginseng virome

\begin{tabular}{|c|c|c|c|c|c|}
\hline Query ID & Length & BLAST description & $\begin{array}{l}\text { Query } \\
\text { cover }\end{array}$ & $\begin{array}{l}\text { Identities } \\
(\%)\end{array}$ & Accession no. \\
\hline c122350_g1_i1 & 299 & $\begin{array}{l}\text { Aristotelia chilensis virus } 1 \text { isolate AcPLV-1 movement protein } \\
\text { and reverse transcriptase genes, complete cds }\end{array}$ & 85 & 73.93 & KJ094314 \\
\hline c85745_g1_i1 & 214 & $\begin{array}{l}\text { Aristotelia chilensis virus } 1 \text { isolate AcPLV-1 movement protein } \\
\text { and reverse transcriptase genes, complete cds }\end{array}$ & 46 & 76.77 & KJ094314 \\
\hline c101531_g1_i1 & 324 & $\begin{array}{l}\text { PREDICTED: Camellia sinensis tobamovirus multiplication pro- } \\
\text { tein 2A-like (LOC114279495), transcript variant X5, mRNA }\end{array}$ & 100 & 84.88 & XM_028221749 \\
\hline c103606_g1_i2 & 308 & $\begin{array}{l}\text { PREDICTED: Daucus carota subsp. sativus tobamovirus multipli- } \\
\text { cation protein } 1 \text { (LOC108204642), transcript variant X2, mRNA }\end{array}$ & 100 & 92.21 & XM_017375367 \\
\hline c119698_g1_i1 & 250 & $\begin{array}{l}\text { PREDICTED: Vitis vinifera tobamovirus multiplication protein } 1 \\
\text { (LOC104878681), mRNA }\end{array}$ & 32 & 88.89 & XM_010649283 \\
\hline c53614_g1_i1 & 9,797 & Turnip mosaic virus isolate $\mathrm{CN} 3$, complete genome & 100 & 99.37 & MH735111 \\
\hline c116721 g3 i1 & 1,011 & Watermelon mosaic virus isolate Buan2-1 2012, complete genome & 99 & 99.6 & KU240094 \\
\hline c110549g1_i1 & 448 & Watermelon mosaic virus isolate C06-666, complete genome & 100 & 95.31 & EU660588 \\
\hline c116728_g1_i1 & 6,782 & $\begin{array}{l}\text { Watermelon mosaic virus isolate Eumseong2-10_2014, complete } \\
\text { genome }\end{array}$ & 100 & 99.59 & KT992074 \\
\hline c113261_g1_i1 & 202 & Watermelon mosaic virus isolate Naju3-1_2012, complete genome & 100 & 96.04 & KU240100 \\
\hline c116735_g1_i1 & 8,541 & Watermelon mosaic virus isolate Sangju3_2013, complete genome & 100 & 95.96 & KT992079 \\
\hline c41181_g1_i1 & 509 & Watermelon mosaic virus isolate Sangju6_2012, complete genome & 100 & 98.62 & KU240105 \\
\hline c107961_g1_i1 & 207 & Watermelon mosaic virus isolate WMV-WS, complete genome & 99 & 97.09 & KX664483 \\
\hline c108825_g1_i1 & 224 & Watermelon mosaic virus isolate WMV-WS, complete genome & 99 & 95.52 & KX664483 \\
\hline c113261_g2_i1 & 354 & $\begin{array}{l}\text { Watermelon mosaic virus isolate Yeongam2_2013, complete } \\
\text { genome }\end{array}$ & 100 & 98.7 & KT992081 \\
\hline c104119_g1_i1 & 229 & $\begin{array}{l}\text { Watermelon mosaic virus isolate Yeongju2-3_2013, complete } \\
\text { genome }\end{array}$ & 100 & 100 & KT992085 \\
\hline c109339_g1_i1 & 240 & $\begin{array}{l}\text { Watermelon mosaic virus isolate Yeongju2-3_2013, complete } \\
\text { genome }\end{array}$ & 100 & 100 & KT992085 \\
\hline c112142_g1_i1 & 373 & $\begin{array}{l}\text { Watermelon mosaic virus isolate Yeongju2-3_2013, complete } \\
\text { genome }\end{array}$ & 100 & 99.73 & KT992085 \\
\hline c98826_g1_i1 & 434 & $\begin{array}{l}\text { Watermelon mosaic virus isolate Yeongju6-1_2013, complete } \\
\text { genome }\end{array}$ & 100 & 99.54 & KT992086 \\
\hline c112889_g1_i2 & 297 & $\begin{array}{l}\text { Watermelon mosaic virus isolate Yeongyang8-1_2013, complete } \\
\text { genome }\end{array}$ & 100 & 99.64 & KT992093 \\
\hline c116688_g4_i1 & 225 & Watermelon mosaic virus Sa genomic RNA, complete genome & 100 & 99.56 & LC412927 \\
\hline c112898_g2_i1 & 322 & Watermelon mosaic virus strain WMV-Fr, complete genome & 100 & 95.34 & AY437609 \\
\hline c93233 g1 il & 316 & Watermelon mosaic virus strain WMV-Fr, complete genome & 100 & 95.25 & AY437609 \\
\hline
\end{tabular}

this is probably related to the regional distribution of plant viral insect vectors such as aphids (Table 3). Tobamovirus was not detected using RT-PCR assay for the single pooled sample with a degenerated primer set for detecting Tobamovirus (Letschert et al., 2002). Therefore, the existence of the Tobamovirus is uncertain; therefore, the most commonly found virus of $P$. ginseng is the WMV. TuMV, on the other hand, is considered the minor virus of $P$. ginseng, given its low infection rate $(0.61 \%)$. In RT-PCR assay using a polled samples, AcV1 was detected by RT-PCR assay using sequence-specific primers, designed based on the AcV1-like contigs from our RNA-Seq data. However, it is unclear whether AcV1 infects $P$. ginseng because only two small contigs (214 nt and $299 \mathrm{nt}$ ), corresponding to the partial regions of the genome of $\mathrm{AcV} 1$, were found in the RNA-Seq data and the pathogenicity of AcV1 was not yet been determined (Villareses et al., 2015). Viruses in the genus Panax that were reported in China, such as TY- 
Table 3. Occurrence, distribution, and infection rate (\%) of WMV in Panax ginseng collected from the cultivation areas located at the 6 provinces

\begin{tabular}{|c|c|c|c|c|}
\hline \multicolumn{2}{|c|}{ Cultivation area } & \multirow{2}{*}{$\begin{array}{c}\begin{array}{c}\text { No. of collected } \\
\text { samples }\end{array} \\
84\end{array}$} & \multirow{2}{*}{$\begin{array}{c}\text { No. of detected } \\
\text { samples }\end{array}$} & \multirow{2}{*}{$\begin{array}{c}\text { Infection rate } \\
(\%)\end{array}$} \\
\hline Gyeonggi-do & Yeoju & & & \\
\hline & Yeoncheon & 34 & 3 & 8.8 \\
\hline & Yangpyeong & 13 & 0 & 0 \\
\hline & Icheon & 28 & 17 & 60.7 \\
\hline & Hwaseong & 33 & 0 & 0 \\
\hline & Anseong & 18 & 11 & 61.1 \\
\hline \multirow[t]{3}{*}{ Gangwon-do } & Hoengseong & 81 & 0 & 0 \\
\hline & Hongcheon & 80 & 1 & 1.3 \\
\hline & Cheorwon & 88 & 0 & 0 \\
\hline \multirow{2}{*}{ Chungcheongbuk-do } & Chungju & 43 & 19 & 44.2 \\
\hline & Goesan & 25 & 5 & 20 \\
\hline \multirow[t]{3}{*}{ Chungcheongnam-do } & Yesan & 19 & 7 & 36.8 \\
\hline & Seosan & 36 & 11 & 30.5 \\
\hline & Sejong & 20 & 10 & 50 \\
\hline \multirow[t]{2}{*}{ Jeollabuk-do } & Gochang & 7 & 6 & 85.7 \\
\hline & Namwon & 2 & 2 & 100 \\
\hline \multirow[t]{2}{*}{ Jeollanam-do } & Yeonggwang & 38 & 38 & 100 \\
\hline & Gangjin & 7 & 7 & 100 \\
\hline Total & 18 areas & 656 & 139 & 21.2 \\
\hline
\end{tabular}

WMV, Watermelon mosaic virus.

LCCNV, PnVA, and PanVY were not found in the RNASeq data from $P$. ginseng. TYLCCNV, PnVA, and PanVY were also not detected by RT-PCR assay. From these results, the distribution of domestic ginseng virus species seems different from those recorded in China; only two viruses (WMV and TuMV) were detected in domestically grown $P$. ginseng by RNA-Seq metatranscriptome analysis and RT-PCR assay (Table 4).

This is the first metatranscriptome analysis of plant virome from $P$. ginseng using NGS-based RNA-Seq and RTPCR based analyses for virus identification and detection and its distribution, which will provide important basic data

Table 4. Summary of metatranscriptome analysis and RT-PCR diagnosis for viruses in Panax ginseng

\begin{tabular}{|c|c|c|c|}
\hline $\mathrm{Name}^{\mathrm{a}}$ & $\begin{array}{l}\text { Metatranscriptome } \\
\text { analysis }\end{array}$ & $\begin{array}{l}\text { RT-PCR } \\
\text { assay }\end{array}$ & Description \\
\hline AcV1 & o & o & $\begin{array}{l}\text { Only } 2 \text { small contigs corresponding to } \mathrm{AcV} 1 \text { were found in metatranscriptome analysis. } \\
\text { It is uncertain whether the virus is } \mathrm{AcV} 1 \text { or novel (unreported) virus. }\end{array}$ \\
\hline Tobamo & ○ & $\times$ & $\begin{array}{l}\text { The presence of Tobamovirus or Tobamo-like-virus has not been confirmed in RT-PCR } \\
\text { assay. }\end{array}$ \\
\hline TuMV & ○ & ○ & Of the 656 samples tested, $3(0.46 \%)$ samples were TuMV-positive in RT-PCR assay. \\
\hline WMV & ○ & $\circ$ & $\begin{array}{l}\text { Of the } 656 \text { samples tested, } 139(21.2 \%) \text { samples were WMV-positive in RT-PCR assay. } \\
\text { WMV of } P \text {. ginseng has been reported in Korea (Jung et al., 2013). }\end{array}$ \\
\hline TYLCCNV & $\times$ & $\times$ & Virus of $P$. notoginseng, reported in China (Li et al., 2014). \\
\hline PnVA & $\times$ & $\times$ & Virus of $P$. notoginseng, reported in China (Guo et al., 2016). \\
\hline PanVY & $x$ & $x$ & Virus of $P$. notoginseng, reported in China (Yan et al., 2010). \\
\hline
\end{tabular}

RT-PCR, reverse transcription polymerase chain reaction.

${ }^{a}$ AcV1, Aristotelia chiliensis virus 1; Tobamo, Tobamovirus multiplication protein; TuMV, Turnip mosaic virus; WMV, Watermelon mosaic virus; TYLCCNV, Tomato yellow leaf curl china virus; PnVA: Panax notoginseng virus A; PanVY: Panax virus Y. 
for the development of virus-free plants. Further research and continuous field monitoring are therefore needed to clarify potential pathogenicity and economic impact of viruses on $P$. ginseng.

\section{Conflicts of Interest}

No potential conflict of interest relevant to this article was reported.

\section{Acknowledgments}

This research was supported by a grant from The Korean Society of Ginseng (KSG).

\section{Electronic Supplementary Material}

Supplementary materials are available at The Plant Pathology Journal website (http://www.ppjonline.org/).

\section{References}

Choi, S.-K., Cho, I.-S., Chung, B.-N., Kim, M.-K., Jung, W.-K. and Choi, G.-S. 2014. Characteristics of watermelon mosaic virus transmission occurring in Korean ginseng. Res. Plant Dis. 20:206-210 (in Korean).

Guo, L., Yang, X., Wu, W., Tan, G., Fang, S., Zhang, S. and Li, F. 2016. Identification and molecular characterization of Panax notoginseng virus A, which may represent an undescribed novel species of the genus Totivirus, family Totiviridae. Arch. Virol. 161:731-7344.

Jung, W.-K., Nam, M., Lee, J. H., Park, C. Y., Kim, B. H., Park, E. H., Lee, M.-A., Kim, M.-K., Choi, H.-S., Lee, J. S., Kim, J.S., Choi, J. K., Kwon, T. R., Lee, K.-W. and Lee, S.-H. 2013. Novel pathogenic strain of watermelon mosaic virus occurred in Insam (Panax ginseng). Res. Plant Dis. 19:331-337 (in Korean).
Lee, S. H., Choi, H. S., Park, J. W. and Lee, J. S. 2006. Detecting primer sets for TuMV, RMV and CMV infecting cruciferae. R.O.K. Patent No. 1006250190000.

Letschert, B., Adam, G., Lesemann, D., Wilingmann, P. and Heinze, C. 2002. Detection and differentiation of serologically cross-reacting tobamoviruses of economical importance by RT-PCR and RT-PCR-RFLP. J. Virol. Methods 106:1-10.

Li, X. J., Liu, F., Li, Y. Y., Zhang, S. Y., Li, M. R., Li, R. H. and Li, F. 2014. First report of Tomato yellow leaf curl China virus with Betasatellite infecting Panax notoginseng. Plant Dis. 98:1284.

Min, H.-G., Park, C. Y., Lee, H.-K., Yeom, Y.-A., Oh, J., Kim, B. S., Lim, S., Yoon, Y. and Lee, S.-H. 2017. A survey of viral disease of proso millet (Panicum miliaceum L.) and sorghum (Sorghum bicolor L.) in South Korea. Res. Plant Dis. 23:262267 (in Korean).

Oh, J., Lee, H.-K., Park, C.-Y., Yeom, Y.-A., Min, H.-G., Yang, H.-J., Jeong, R.-D., Kim, H., Moon, J.-S. and Lee, S.-H. 2018. First report of Southern tomato virus in Tomato (Solanum lycopersicum) in Korea. Plant Dis. 102:1467.

Park, C. Y., Park, J., Kim, H., Yi, S.-I. and Moon, J. S. 2019. First report of citrus leaf blotch virus in Satsuma mandarin in Korea. J. Plant Pathol. 101:1229.

Villacreses, J., Rojas-Herrera, M., Sanchez, C., Hewstone, N., Undurraga, S. F., Alzate, J. F., Manque, P., Maracaja-Coutinho, V. and Polanco, V. 2015. Deep sequencing reveals the complete genome and evidence for transcriptional activity of the first virus-like sequences identified in Aristotelia chilensis (Maqui Berry). Viruses 7:1685-1699.

Yan, Z. L., Song, L. M., Zhou, T., Zhang, Y. J., Li, M. F., Li, H. F. and Fan, Z. F. 2010. Identification and molecular characterization of a new potyvirus from Panax notoginseng. Arch. Virol. 155:949-957.

Yang, H.-J., Oh, J., Lee, H.-K., Lee, D.-S., Kim, S.-Y., Kim, M.H., Park, C.-Y., Kim, H., Lee, S.-I., Jeong, R.-D., Moon, J.-S. and Lee, S.-H. 2019. First report of citrus vein enation virus in Satsuma mandarin (Citurs unshiu) in Korea. Plant Dis. 103:2703. 